\title{
PERIKANAN PARI ARTISANAL DI LAUT JAWA
}

\author{
Agustinus Anung P. Widodo" dan Johanes Widodo")
}

\begin{abstract}
ABSTRAK
Penelitian mengenai perikanan pari artisanal di perairan Laut Jawa telah dilakukan dalam tahun 20022003 melalui: (i) observasi di pusat-pusat pendaratan ikan (DKI Jakarta, Cirebon, Pekalongan, Juwana, dan Brondong), (ii) observasi di atas kapal, dan (iii) enumerator. Hasil penelitian menunjukkan bahwa alat tangkap penting pada perikanan pari artisanal berupa jaring dogol, jaring liongbun, dan pancing senggol. Ikan pari yang teridentifikasi paling tidak ada 36 jenis yang didominasi oleh Himantura gerrardi $(30,07 \%)$, Dasyatis kuhlii $(18,57 \%)$, Himantura bleekeri $(11,58 \%)$, Aetoplatea zonura $(6,28 \%)$, dan Himantura jenkinsii $(5,36 \%)$. Jaring dogol merupakan alat tangkap yang paling efektif namun kurang bersifat selektif, di mana $>50 \%$ dari total hasil tangkapan berupa ikan-ikan muda. Jaring liongbun dan pancing senggol tergolong selektif, dimana ikan pari muda tertangkap dengan jumlah $<50 \%$ dari total hasil tangkapannya. Daerah penangkapan ikan pari di Laut Jawa dapat digolongkan menjadi dua yaitu inshore dan offshore. Pada daerah inshore hasil tangkapan didominasi ikan-ikan muda, sedangkan daerah offshore umumnya tertangkap ikan pari yang telah dewasa. Terjadi penurunan CPUE pada 7 tahun terakhir yaitu dari 1,116 ton/unit pada tahun 1997 menjadi 0,822 ton/unit tahun 2002. Usaha penangkapan agar ditujukan pada alat tangkap yang selektif yaitu jaring liongbun dan pancing senggol dengan kegiatan penangkapan dilakukan di perairan offshore.
\end{abstract}

\section{ABSTRACT: The artisanal rays fisheries in Java Sea. By: Agustinus Anung $P$. Widodo and Johanes Widodo}

\begin{abstract}
Research on artisanal rays fisheries in the Java Sea was conducted in 2002-2003 through observations both in the fish landings (Jakarta, Cirebon, Pekalongan, Juwana, and Brondong) on boat observer and enumerator. Research results show that the main fishing gears were dogol (danish seine), jaring liongbun (bottom gillnet), and pancing senggol (bottom longline without bait). There were at least 36 species of rays successfully identified that dominated by Himantura gerrardi (30.07\%), Dasyatis kuhlii (18.57\%), Himantura bleekeri (11.58\%), Aetoplatea zonura (6.28\%), and Himantura jenkinsii (5.36\%). Dogol is the most effective gear but not sufficiently selective, more than $50 \%$ of total catch were young. On the other hand liongbun and pancing sengggol were more selective, that less than $50 \%$ of total catch were young rays. The fishing ground of rays in Java Sea classified into two categories i.e., inshore and offshore waters. The rays cought in inshore fishing ground are dominated by young rays. Those cought in offshore fishing ground are of adult (mature) rays. CPUE decreased from 1.116 ton/unit gear in 1997 to 0.822 ton/unit gear in 2002. The rays fisheries are recomended to use selective gears i.e. jaring liongbun and pancing senggol, with fishing ground in the offshore.
\end{abstract}

KEYWORDS: $\quad$ artisanal rays fisheries, Java Sea

\section{PENDAHULUAN}

Laut Jawa merupakan perairan paparan benua (continental shelf) dengan kedalaman rata-rata 40 meter (Durand \& Petit, 1997). Perairan ini merupakan daerah penangkapan ikan (fishing ground) yang paling luas di kawasan barat Indonesia. Sumber daya ikan pari di perairan Laut Jawa sudah lama dimanfaatkan sebagai hasil tangkap sampingan, terutama oleh nelayan dari pantai utara Jawa. Ikan ini tergolong ke dalam ikan bertulang rawan (Elasmobranchii). Sumber daya ikan pari tergolong rentan terhadap tekanan penangkapan. Hal ini disebabkan karena ikan pari mempunyai sifat biologis antara lain: tumbuh lambat, berumur panjang, dan fekunditas rendah.

Ikan pari ditangkap untuk dikonsumsi dagingnya dan kulitnya sebagai bahan baku fesyen. Pada awalnya, ikan pari tertangkap sebagai bagian tangkapan dari alat tangkap yang target utamanya udang atau ikan yang mempunyai nilai ekonomis relatif tinggi. Sejalan dengan perkembangan dan permintaan pasar akan komoditas ikan pari yang terus naik, sekitar 2-3 tahun terakhir ikan pari menjadi sasaran utama banyak nelayan di Laut Jawa. Beberapa nelayan yang berasal dari pantai timur Sumatera melakukan penangkapan ikan pari di Laut Jawa dengan menggunakan jaring insang khusus. Selanjutnya nelayan lokal pantai utara Jawa juga menciptakan alat tangkap khusus untuk menangkap ikan pari berupa rawai dasar yang juga didisain khusus.

Selama ini Indonesia belum menaruh perhatian serius terhadap spesies-spesies ikan yang justru menjadi perhatian dunia, seperti halnya ikan-ikan Elasmobranchii. Oleh karena itu, sekarang merupakan saat yang tepat untuk memulai lebih serius melakukan penelitian ikan-ikan Elasmobranchii,

\footnotetext{
"Peneliti pada Balai Riset Perikanan Laut, Jakarta
} 
termasuk ikan pari di dalamnya. Informasi yang akurat dari hasil penelitian sangat berguna sebagai dasar kegiatan pemanfaatan (eksploitasi) yang berkelanjutan (sustainable) dan sekaligus mendukung program International Plan of Action (IPOA) dari FAO berkaitan dengan konservasi dan pengelolaan dari Elasmobranchii. Selanjutnya IPOA harus diterjemahkan menjadi National Plan of Action (NPOA) terutama bagi negara-negara yang melakukan pemanfaatan ikan-ikan Elasmobranchii seperti Indonesia.

\section{BAHAN DAN METODE}

Penelitian dilakukan dalam tahun 2001-2002 di mana sampel diambil secara acak berlapis (stratified random sampling). Lokasi penelitian adalah tempat pendaratan ikan di pantai utara Jawa yang merupakan pendaratan ikan pari hasil tangkapan di perairan Laut Jawa. Tempat pendaratan ikan meliputi Pelabuhan Perikanan Muara Angke (DKI-Jakarta), Pelabuhan Perikanan Kejawanan (Jawa Barat), Pelabuhan Perikanan Pekalongan, Juwana (Jawa Tengah), dan Pelabuhan Perikanan Brondong (Jawa Timur). Selain itu, data diperoleh dengan mengikuti operasi penangkapan ikan pari dengan jaring dogol, jaring liongbun, dan pancing senggol.

Jenis data yang diambil meliputi: deskripsi masingmasing alat tangkap yang menangkap ikan pari, taktik/strategi penangkapan dan posisi daerah penangkapan dengan mengikuti operasi penangkapan kapal komersial di laut dan komposisi jenis hasil tangkapan, ukuran (lebar cawan- $B_{d}$ ), dan komposisi jenis kelamin serta ukuran pertama kali dewasa. Ikan sampel diidentifikasi menurut referensi ikan pari dari Tarp dan Kailola (1982), Last and Stevens (1994), Isa ot al., (1998). Masing-masing jenis dihitung dan dikompilasi berurutan untuk mengetahui dominasi jenis ikan pari yang ditangkap di Laut Jawa. Ukuran (lebar disk- $B_{d}$ ) masing-masing jenis yang dominan disusun hingga diperoleh sebaran ukurannya.

Penentuan umur ikan pari hanya ditujukan pada ikan jantan. Ikan jantan muda (immature) mempunyai ukuran klasper lebih pendek dari ukuran sirip perut (pelfic fin), ikan mulai dewasa (maturing) mempunyai ukuran klasper sama panjang dengan ukuran sirip perut dan ikan telah dewasa (mature) mempunyai ukuran klasper lebih panjang dari sirip perutnya. Ukuran ikan pertama dewasa (maturing) di singkat dengan $\mathrm{Bm}$, merupakan rerata ukuran ikan dari sejumlah sampel ikan satu spesies yang pertama dewasa.

Performansi alat tangkap didasarkan pada tingkat selektivitasnya. Alat tangkap dianggap tidak selektif bila $>50 \%$ total hasil tangkapnya berupa ikan pari muda dan sebaliknya. Ikan pari muda didefinisikan sebagai ikan pari yang ukuran $B d$-nya lebih kecil dari rerata ukuran Bm-nya. Hasil tangkapan per unit upaya (CPUE) selama 7 tahun dari masing-masing alat tangkap dihitung dari data statistik perikanan. Satuan upaya yang digunakan adalah unit alat tangkap baku, sedangkan satuan hasil tangkapan digunakan ton.

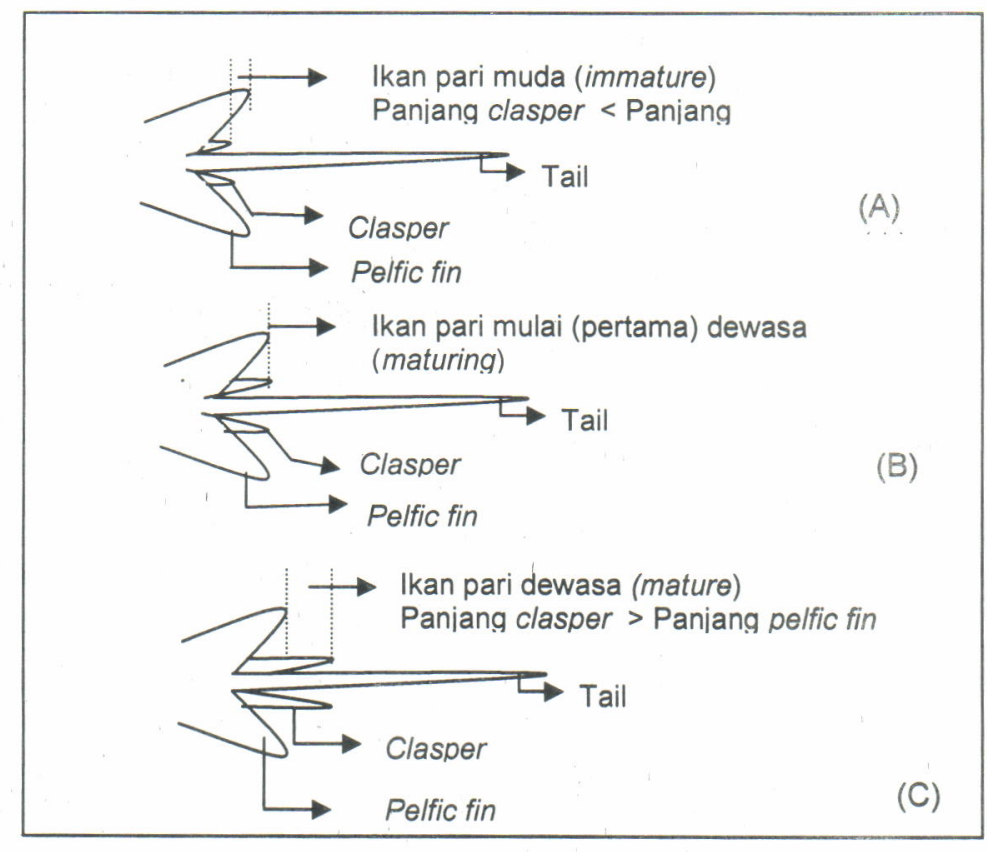

Gambar 1. Tiga tingkat kedewasaan ikan pari jantan.

Figure 1. The three maturity stages of male rays. 


\section{HASIL DAN BAHASAN}

\section{Alat Tangkap}

Selama ini ikan pari di Laut Jawa ditangkap oleh nelayan tradisional. Paling tidak ada 10 jenis alat tangkap yang memproduksi ikan pari di Laut Jawa, yaitu: dogol (Danish seine), payang (lampara net), pukat pantai (beach seine), jaring insang hanyut (drift gillnet), jaring insang tetap (bottom gillnet), jaring trammel (trammel net), rawai dasar (bottom long line), pancing tangan (hand line), sero (guiding barrier), dan bubu (portable traps). Kapal yang digunakan untuk mengoperasikan alat-alat tangkap tersebut berukuran 5-15 GT dengan kekuatan mesin penggerak 12-60 HP. Kesepuluh alat tangkap tersebut sebenarnya bukan ditujukan untuk menangkap ikan pari. Tujuan utama (target species) sebenarnya adalah udang atau ikan demersal.

Sejak 2-3 tahun terakhir, banyak nelayan mengembangkan teknologi alat tangkap yang khusus menangkap ikan pari yaitu jaring liongbun dan pancing senggol. Perkembangan teknologi alat tangkap lain adalah adanya modifikasi jaring dogol atau cantrang atau arad atau lampara dasar. Modifikasi yang dimaksud adalah penggunaan siwakan (otter board) yang berfungsi sebagai pembuka mulut jaring. Alat tangkap ini juga dioperasikan dengan cara ditarik sepanjang dasar perairan dengan kapal bermotor. Modifikasi ini mengakibatkan alat tangkap menjadi sangat efektif menangkap ikan-ikan demersal, termasuk pari sehingga seperti jaring trawl.

\section{Jaring liongbun}

Jaring liongbun tergolong alat tangkap jaring insang (gillnet) dasar. Jaring ini pada awalnya khusus ditujukan untuk menangkap ikan pari jenis nungnang atau liongbun (Rhyncobatus jiddensis) untuk diambil siripnya. Dalam kenyataan, pengoperasian jaring liongbun di Laut Jawa justru $70 \%$ hasil tangkapannya ikan pari yang lain, terutama Himantura gerrardi, H.bleekeri, dan Aetoplatea zonura. Maka selanjunya jaring ini seolah khusus ditujukan untuk menangkap ikan pari. Ikan pari yang tertangkap jaring ini umumnya tertangkap secara terjerat (gilled) atau terpuntal (entangled).

Jaring liongbun mempunyai spesifikasi sebagai berikut: jaring (webbing) terbuat dari bahan nilon multifilamen d-21 dan ukuran mata jaring (mesh size) $50 \mathrm{~cm}$ dengan hanging ratio 0,55 . Ukuran panjang jaring (ris atas) adalah $6.500 \mathrm{~cm}$ dan tinggi jaring 500 cm (Gambar 2).

Spesifikasi jaring liongbun adalah ukuran mata jaringnya tergolong sangat besar dibandingkan ukuran mata jaring gillnet biasa yang digunakan untuk menangkap ikan pelagis besar yang hanya berukuran $10-12,5 \mathrm{~cm}$ atau gillnet untuk ikan demersal yang umumnya mempunyai ukuran mata $5-7,5 \mathrm{~cm}$. Karena konstruksinya yang khas tersebut, maka jaring liongbun cocok jika dikhususkan untuk menangkap ikan pari yang memang berukuran relatif besar. Jaring liongbun dioperasikan dengan kapal kayu bermotor ukuran 30-90 GT. Setiap kapal mengoperasikan jaring rata-rata 120 tinting. Armada

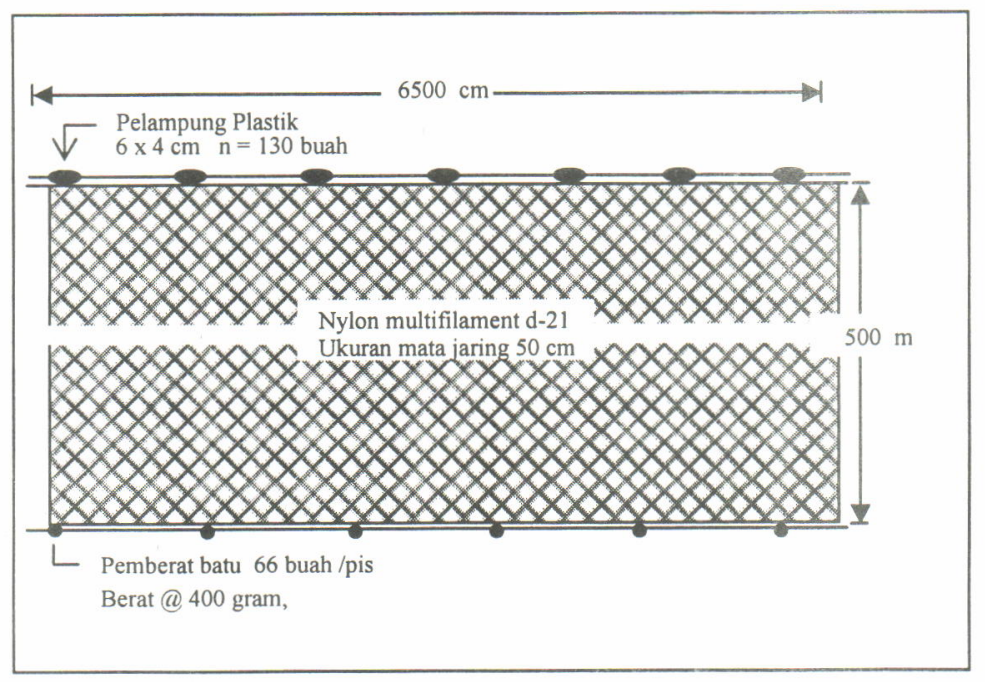

Gambar 2. Disain dan konstruksi umum jaring liongbun yang dioperasikan di Laut Jawa. Figure 2. Common design and construction of bottom gillnet operated in the Java Sea. 
penangkapan jaring liongbun berbasis di Pelabuhan Perikanan Muara Angke (DKI Jakarta) dan Pelabuhan Perikanan Kejawanan (Cirebon-Jawa Barat). Satu trip penangkapan kapal jaring liongbun berlangsung antara 30-90 hari. Satu hari mengoperasikan alat sebanyak satu kali.

\section{Pancing senggol}

Pancing senggol adalah pancing yang didesain seperti pancing rawai dasar dengan tujuan khusus untuk menangkap ikan pari. Dalam pengoperasiannya pancing senggol tidak menggunakan umpan, sehingga pancing senggol berfungsi seperti halnya trap. Ikan pari yang tertangkap adalah yang secara kebetulan terkait oleh mata pancing saat berenang di dasar perairan.

Desain dan konstruksi umum pancing senggol yang dioperasikan di Laut Jawa adalah: tali utama (main line) terbuat dari PE $\varnothing 3 \mathrm{~mm}$ dengan panjang total berkisar 12.000-24.000 meter. Tali cabang (branch line) terbuat dari PE $\varnothing 2,5 \mathrm{~mm}$ dengan panjang $40 \mathrm{~cm}$. Tali cabang diikatkan pada tali utama dengan jarak satu dengan lainnya sekitar $32-40 \mathrm{~cm}$. Jumlah tali cabang pada 1 unit pancing senggol umumnya antara 3.000-6.000 buah. Pada setiap ujung tali cabang dilkatkan sebuah mata pancing. Mata pancing pada pancing senggol tidak mempunyai mata kait (seperti pada mata pancing huhate). Bahan mata pancing umumya adalah baja anti karat (stainless stee), Ø 1,6 mm (Gambar 3).

Pancing senggol dioperasikan dengan menggunakan kapal bermotor ukuran sekitar 6-30 GT dengan kekuatan mesin antara 12-120 HP. Armada penangkap ikan pari dengan pancing senggol ukuran kapal 6-10 GT banyak ditemui di pelabuhan perikanan Gebang (Cirebon), serta Pekalongan, dan sekitarnya. Trip penangkapan armada pancing senggol di Cirebon serta Pekalongan dan sekitarnya umumnya 1-3 hari. Armada pancing senggol dengan kapal ukuran sekitar 30 GT banyak ditemukan di Juwana (Pati-Jawa Tengah). Satu trip penangkapan umumnya mencapai 20-30 hari. Satu hari mengoperasikan sebanyak dua kali. Hasil tangkapan umumnya seperti yang tertangkap pada jaring liongbun, yaitu: Himantura gerrardi, H. bleekeri, dan Aetplatea zonura.

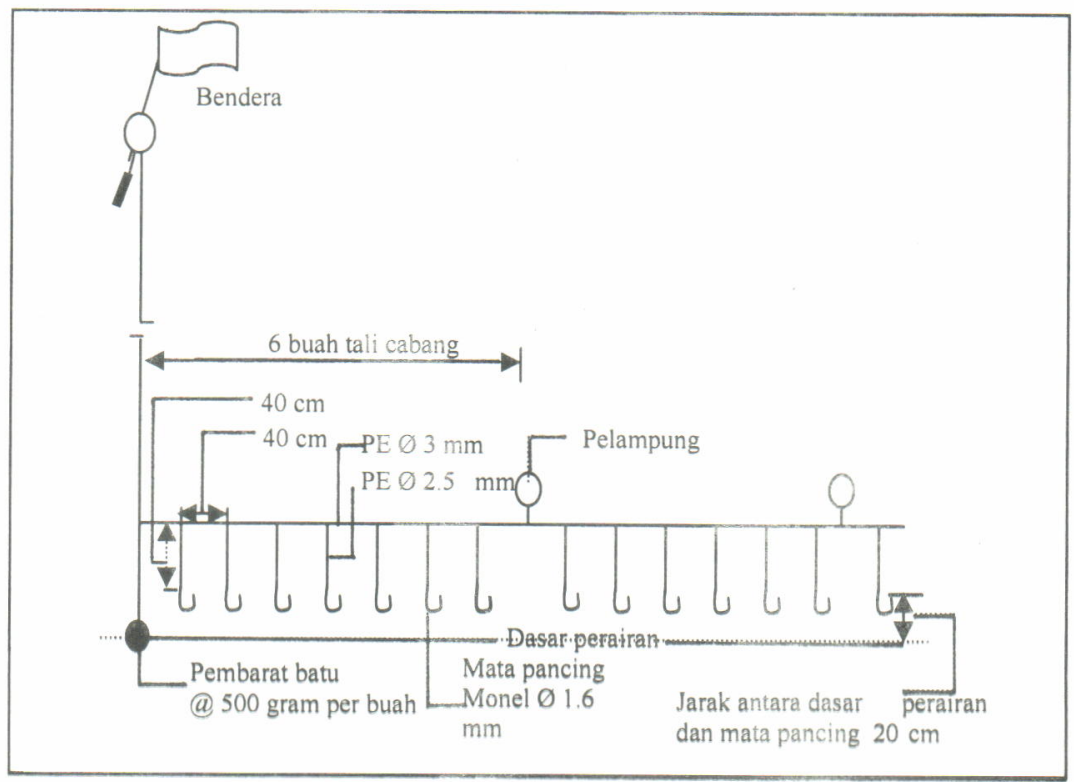

Gambar 3.

Figure 3.

Desain umum pancing senggol yang dioperasikan di Laut Jawa. Common design of bottom longline operated in the Java Sea.

\section{Jaring dogol}

Jaring dogol atau cantrang atau lampara dasar (Danish seine) termasuk alat tangkap ikan jenis pukat dasar (bottom seine) (Andreev, 1962). Alat tangkap in ditujukan untuk menangkap ikan demersal termasuk ikan pari. Konstruksi umum jaring dogol adalah terdiri dari 3 bagian. yaitu sayap (wing) di bagian depan, terbuat dari jaring nilon multifilamen $\mathrm{d}-15$ ukuran mata 5-6 inci, badan (body) di bagian tengah terbuat dari jaring nilon multifilament $\mathrm{d}-12$ ukuran mata $1,5-5$ inci dan kantong (codend) terbuat dari jaring nilon multifilament d-12 ukuran mata 3/4 inci (Gambar 4).

Bagian pangkal depan (sayap) dibiarkan terbuka dan berfungsi sebagai mulut jaring. Sedangkan ujung dari bagian belakang (kantong) diikat sehingga saat dioperasikan ikan yang telah tertangkap tidak keluar kembali.

Dalam pengoperasiannya, jaring ini dilengkapi siwakan (otter board) yang berfungsi sebagai 


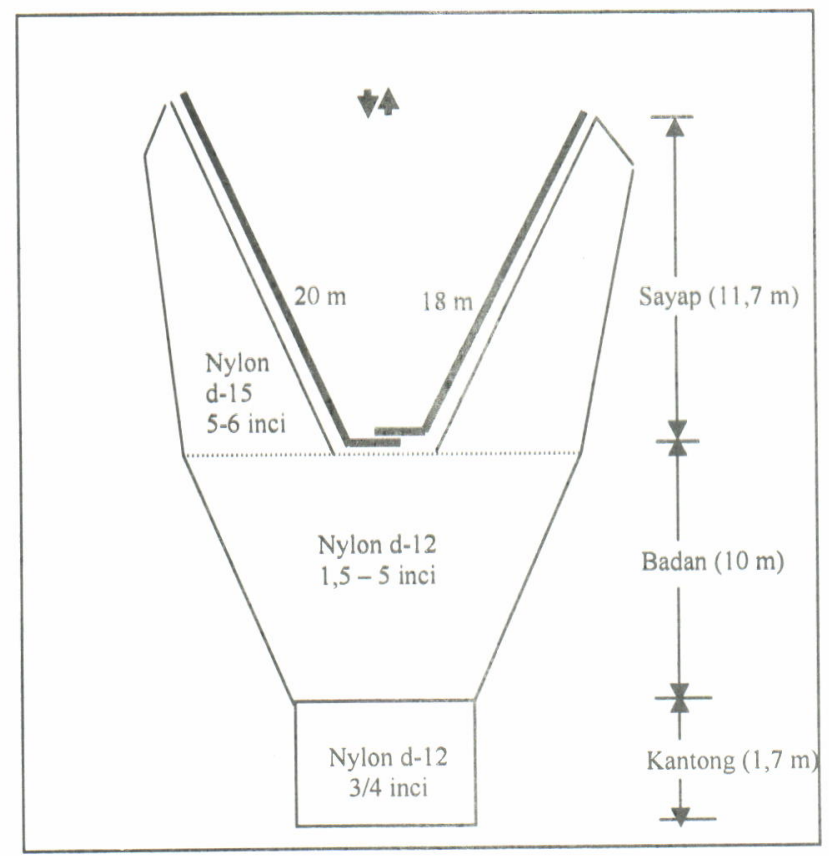

Gambar 4. Disain umum jaring dogol yang dioperasikan di Laut Jawa.

Figure 4. Common design of danish seine operated in the Java Sea.

pembuka mulut. Jaring dioperasikan dengan cara ditarik dengan perahu/kapal bermotor sepanjang dasar perairan. Ikan yang telah masuk melalui mulut akan tertampung di bagian kantong seperti halnya jaring trawl. Jaring dogol dioperasikan dengan kapal bermotor ukuran antara 10-30 GT dengan tenaga penggerak antara 30-100 HP. Armada jaring dogol yang menggunakan kapal kecil sekitar 10 GT ditemukan di seluruh daerah penelitian. Armada jaring dogol dengan kapal ukuran besar (>30 GT) banyak ditemukan di pelabuhan Juwana. Lama trip kapal jaring dogol ukuran kecil umumnya 1 hari per trip. Armada jaring dogol dengan kapal besar umumnya 20 hari per trip. Kapal jaring dogol melakukan tawur jaring rata-rata delapan kali per hari.

Alat tangkap lainnya, yaitu: payang (lampara net), pukat pantai (beach seine), jaring insang hanyut (drift gillnet), jaring insang tetap (bottom gillnet), jaring trammel (trammel net), rawai dasar (bottom longline), pancing tangan (hand line), sero (guiding barrier), dan bubu (portable traps) tidak dibahas secara lebih mendalam karena kurang memiliki arti penting pada perikanan pari di Laut Jawa.

\section{Daerah Penangkapan}

Ikan pari hidup di dekat dasar perairan yang lembek (berlumpur), lumpur pasir, dasar keras, dan bahkan yang berbatu atau koral (Compagno, 1999). Berdasarkan hasil wawancara dengan nahkoda kapal penangkap ikan pari dan hasil pengamatan langsung dengan mengikuti operasi penangkapan ikan pari dengan pancing senggol dan jaring dogol, daerah penangkapan ikan pari di Laut Jawa dapat dibedakan menjadi dua: (1) dekat pantai-inshore (< 12 mil) yaitu daerah penangkapan $A$, dan (2) jauh dari pantaioffshore (> 12 mil) yaitu daerah penangkapan B (Gambar 5).

Daerah penangkapan inshore (A), merupakan daerah penangkapan bagi armada jaring dogol, jaring trammel, payang, gillnet dasar, dan pancing senggol dengan kapal berukuran 6-10 GT. Daerah penangkapan offshore (B) merupakan daerah penangkapan armada penangkapan jaring liongbun dari Muara Angke (Jakarta) dan Kejawanan (Cirebon) serta armada pancing sengggol dan jaring dogol dari Juwana (Pati-Jawa Tengah) dengan kapal berukuran $>30 \mathrm{GT}$.

\section{Musim Penangkapan}

Musim penangkapan biasanya direpresentasikan dengan banyaknya ikan yang tertangkap dan didaratkan di pusat-pusat pendaratan ikan. Kemampuan melakukan operasi penangkapan ikan oleh kapal-kapal komersial tradisional (artisanal) seperti pada umumnya yang dilakukan nelayan pantai utara Jawa sering terkendala oleh kondisi laut yang kurang bersahabat. Laut Jawa sangat dipengaruhi oleh siklus muson. Siklus muson yang terjadi di Laut Jawa adalah arus dari arah timur pada musim barat dan arus dari arah barat pada musim muson tenggara (Durand \& Petit, 1997). Pada musim barat, angin bertiup sangat kencang dan arus begitu kuat. Musim barat di perairan Laut Jawa terjadi antara bulan September-Januari. Pada bulan-bulan tersebut, nelayan pantai utara Jawa sering tidak dapat melaut, sehingga produksi perikanan secara umum menurun termasuk produksi ikan pari (Gambar 6). 


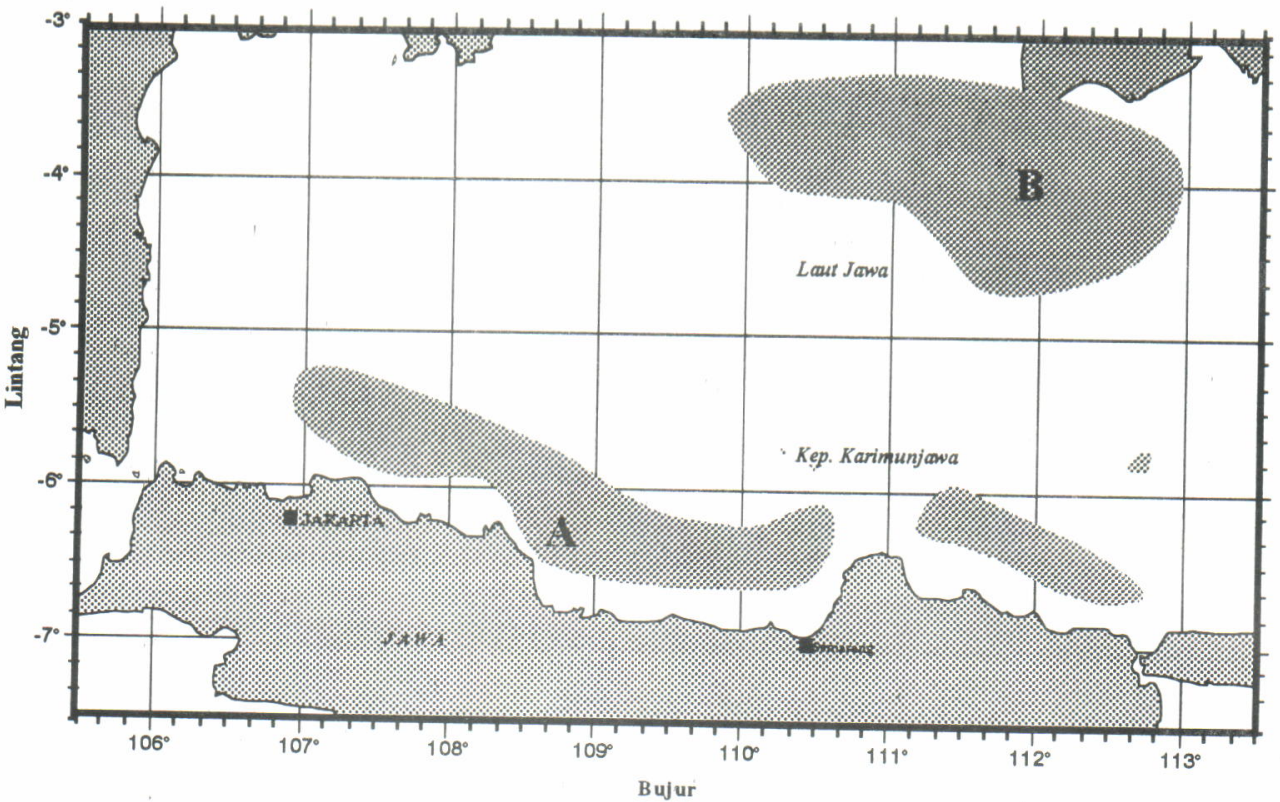

Gambar 5. Daerah penangkapan ikan pari di Laut Jawa, (A) daerah penangkapan pantai (inshore) dan (B) Figure $5 . \quad$ daerah penangkapan lepas pantai (offshore). The fishing ground of rays in the Java Sea: $(A)$ inshore fishing ground and $(B)$ offshore fishing
ground.

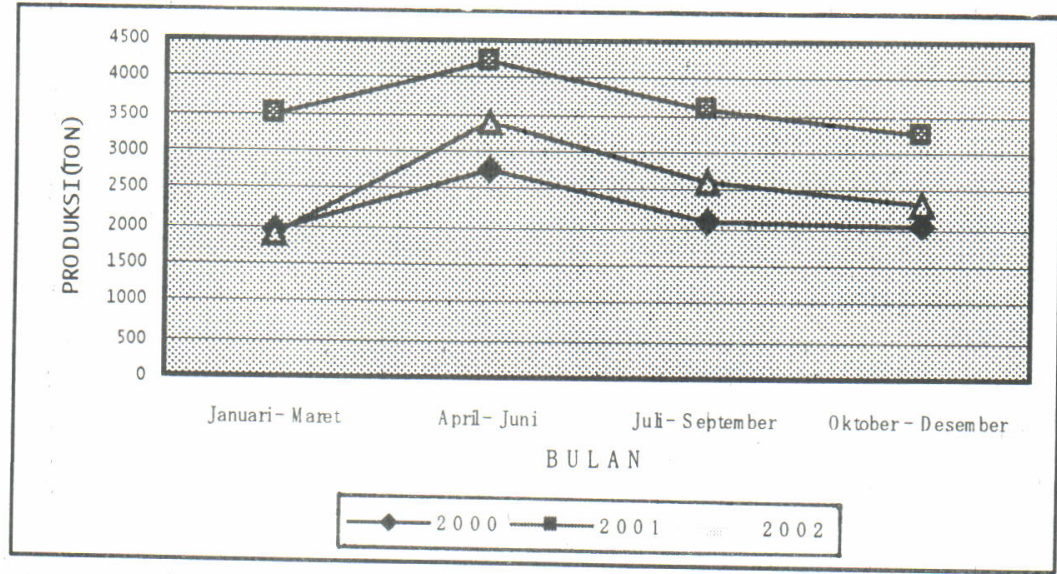

Sumber/Source: Statistik Perikanan Provinsi DKI Jakarta, Jawa Barat, dan Jawa Timur 2000-2002

Gambar 6. Hasil tangkapan ikan pari dari Laut Jawa yang yang didaratkan di DKI Jakarta, Jawa Barat, dan

Figure 6. Jawa Timur menurut bulan yang menggambarkan musim penangkapan. Landings of rays from the Java Sea in Jakarta, West Java, and East Java according to seasonal
catching.

\section{Hasil Tangkapan \\ Jenis ikan}

Pengamatan terhadap jenis-jenis ikan pari yang didaratkan di pusat-pusat pendaratan ikan di daerah penelitian menunjukkan bahwa paling tidak ada 36 jenis (spesies) ikan pari. Adapun jenis ikan pari didominasi oleh spesies-spesies sebagai berikut: Himantura gerrardi $(30,07 \%)$, Dasyatis kuhlii $(18,57 \%)$, Himantura bleekeri $(11,58 \%)$, Aetoplatea zonura $(6,28 \%)$, dan Himantura jenkinsii $(5,36 \%)$.

\section{Ukuran ikan}

Ukuran lebar cawan $\left(B_{d}\right)$ jenis ikan pari dominan yang tertangkap di perairan Laut Jawa dan didaratkan di pusat-pusat pendaratan ikan di pantai utara Jawa secara umum tanpa dipisahkan berdasarkan alat tangkapnya adalah seperti disajikan pada Tabel 1. Dari Tabel 1 dapat diinformasikan bahwa Himantura gerrardi tertangkap di Laut Jawa pada kisaran ukuran lebar cawan $\left(B_{d}\right)$ 11-120 cm dengan rerata ukuran $B d$ pertama kali dewasa $\left(B_{m}\right) 45 \mathrm{~cm}$. Ikan pari jenis 
Tabel 1. Kisaran ukuran lebar cawan ikan $\left(B_{d}\right)$, rataan lebar ikan pertama kali dewasa $\left(B_{m}\right)$ beberapa jenis ikan pari yang dominan yang tertangkap di Laut Jawa

Table 1. Range width of disk $\left(B_{d}\right)$, average width of the first mature $\left(B_{m}\right)$ individuals of dominant rays caugth in the Java Sea

\begin{tabular}{|c|c|c|c|c|c|}
\hline \multirow[b]{2}{*}{ No } & \multirow{2}{*}{ Spesies } & \multicolumn{2}{|c|}{$\mathrm{B}_{\mathrm{d}}(\mathrm{CM})$} & \multirow{2}{*}{$\begin{array}{l}\text { Rataan } B_{m} \\
(\mathrm{~cm})\end{array}$} & \multirow{2}{*}{$\begin{array}{c}\mathbf{N} \\
\text { (ekor) }\end{array}$} \\
\hline & & Minimum & Maksimum & & \\
\hline 1 & Himantura gerrardi & 11 & 120 & 45 & 1524 \\
\hline 2 & Dasyatis kuhlii & 10 & 40 & 24 & 919 \\
\hline 3 & H. bleekeri & 27 & 126 & 58 & 715 \\
\hline 4 & Aetoplatea zonura & 28 & 156 & 53 & 595 \\
\hline 5 & H. jenkinsii & 33 & 199 & 76 & 404 \\
\hline
\end{tabular}

Keterangan/Remarks:

$\mathrm{B}_{\mathrm{d}}$ : Lebar disk ikan pari

$\mathrm{B}_{\mathrm{m}}$ : ukuran rerata lebar disk ikan pari pertama kali dewasa

$\mathrm{N}$ : jumlah sampel

Dasyatis kuhlii tertangkap pada kisaran ukuran $\left(B_{d}\right)$ $10-40 \mathrm{~cm}$ dengan rerata $B_{m} 24 \mathrm{~cm}$. Ikan pari jenis $H$. bleekeri tertangkap pada kisaran ukuran $B_{d}$ 27-126 $\mathrm{cm}$ dengan rerata $B_{m} 58 \mathrm{~cm}$. Ikan pari jenis Aetoplatea zonura tertangkap pada kisaran ukuran $\mathrm{B}_{\mathrm{d}}$ 28-156 cm dengan rerata $B_{m} 53 \mathrm{~cm}$. Ikan pari jenis $H$. jenkinsii tertangkap pada kisaran ukuran $B_{d}$ 33-199 $\mathrm{cm}$ dengan rerata $B_{m} 76 \mathrm{~cm}$.

Sebaran ukuran ikan pari dari masing-masing jenis

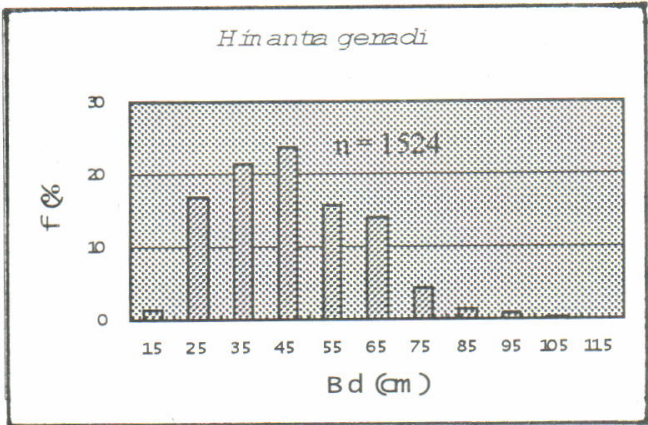

yang dominan disajikan pada Gambar 7 a-e . Dilihat dari sebaran ukuran lebar disk $\left(B_{d}\right)$ ikan pari yang dominan (Gambar 6a-e) yang didaratkan di pusatpusat pendaratan ikan di pantai utara Jawa menunjukkan bahwa pada umumnya lebih dari $50 \%$ ikan pari berukuran $B_{d}$ lebih kecil dari rerata ukuran pertama kali ikan mulai dewasa $\left(B_{m}\right)$. Hal ini menunjukkan bahwa lebih dari $50 \%$ ikan yang tertangkap berupa ikan pari muda yang belum sempat melakukan reproduksi.

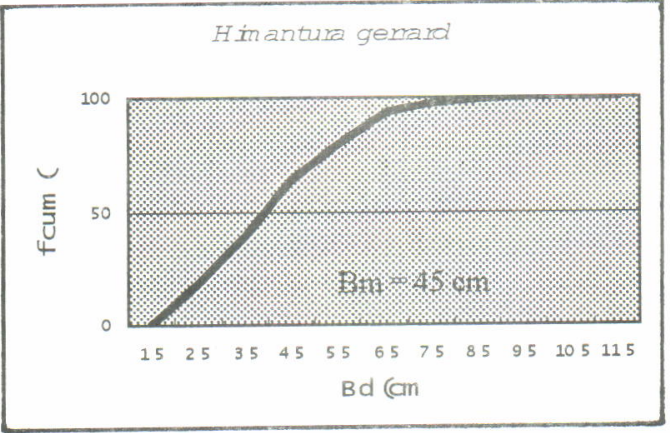

Gambar 7a. Sebaran ukuran lebar disk (Bd) dan frekuensi kumulatif Himantura gerradi yang tertangkap di Laut Jawa.

Figure 7a. Distribution of disk width $(\mathrm{Bd})$ and commulative frequency of Himantura gerradi caught in the Java Sea.
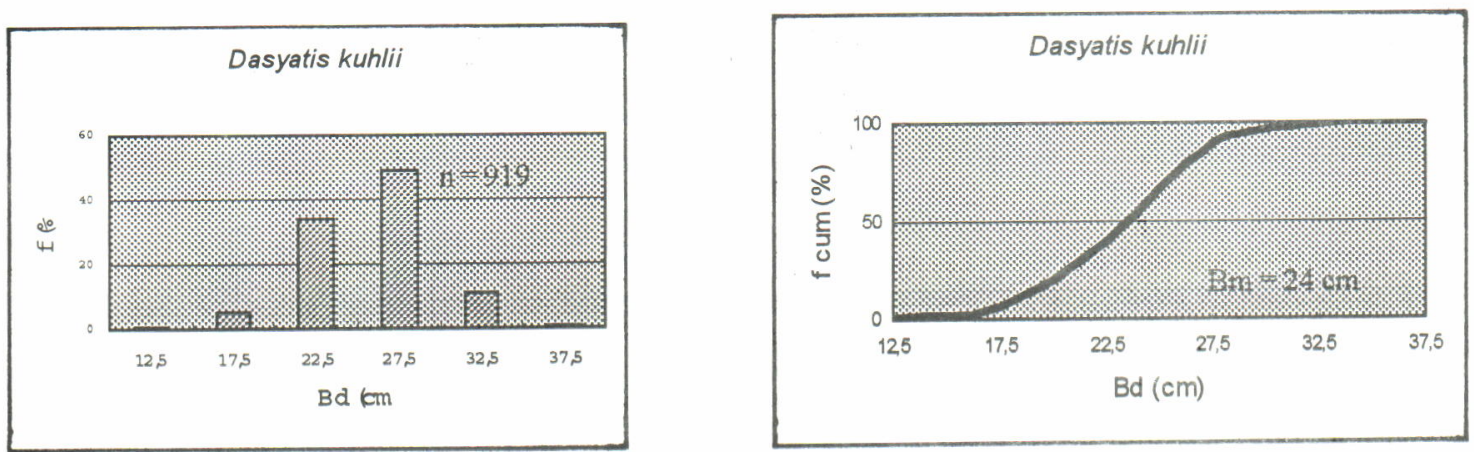

Gambar 7b. Sebaran ukuran lebar disk (Bd) dan frekuensi kumulatif ikan Dasyatis kuhlii yang tertangkap di Laut Jawa.

Figure $7 b$. Distribution of disk width $(\mathrm{Bd})$ and commulative frequency of Dasyatis kuhlii caught in the Java Sea. 

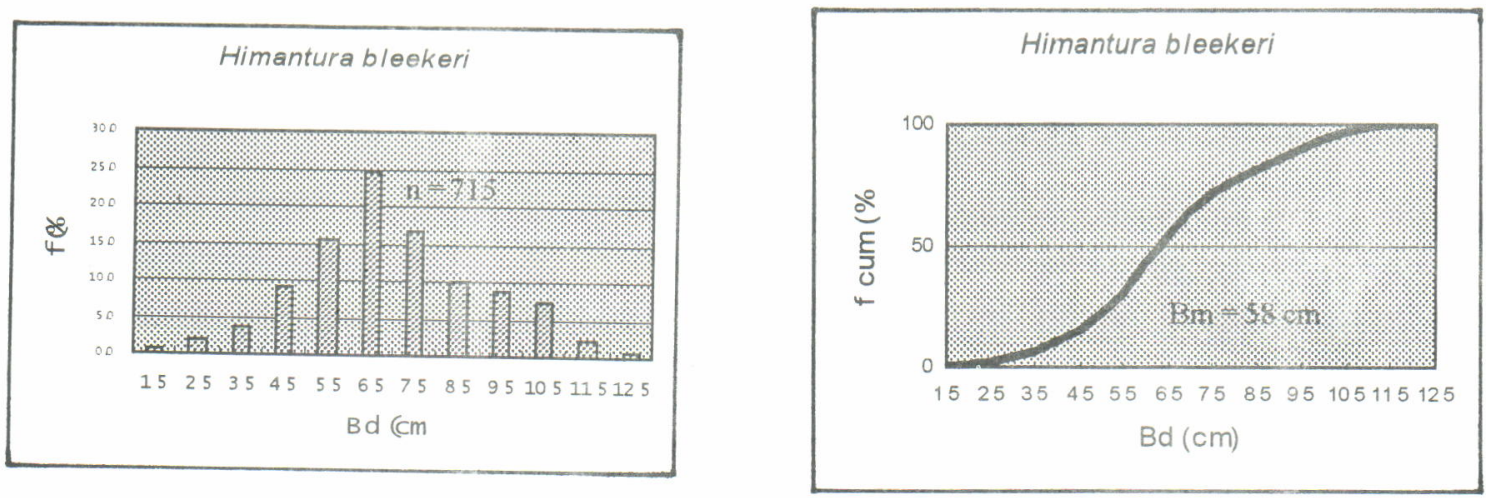

Gambar 7c. Sebaran ukuran lebar disk (Bd) dan frekuensi kumulatif ikan Himantura bleekeri yang

Figure 7c. tertangkap di Laut Jawa. Figure 7c. Distribution of disk width $(B d)$ and commulative frequency of Himantura bleekeri caught in the
Java Sea.
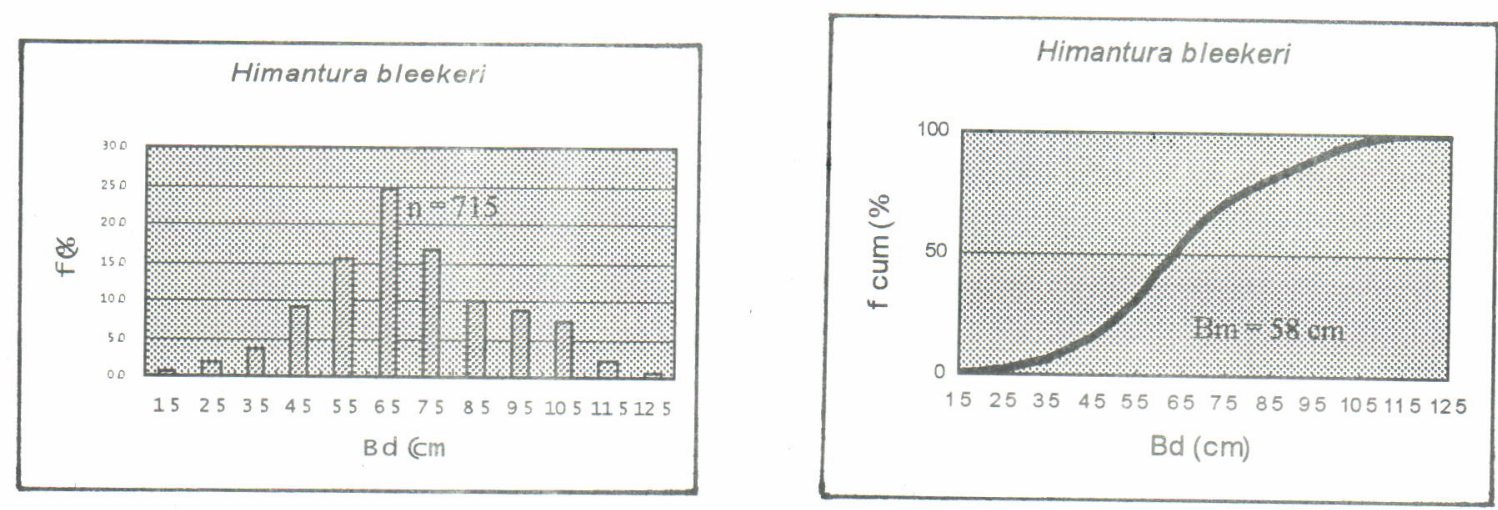

Gambar 7d. Sebaran ukuran lebar disk (Bd) dan frekuensi kumulatif ikan Aetoplatea zonura yang tertangkap

Figure $7 d$. Distribution of disk width $(B d)$ and commulative frequency of Aetoplatea zonura caught in the Java Sea.
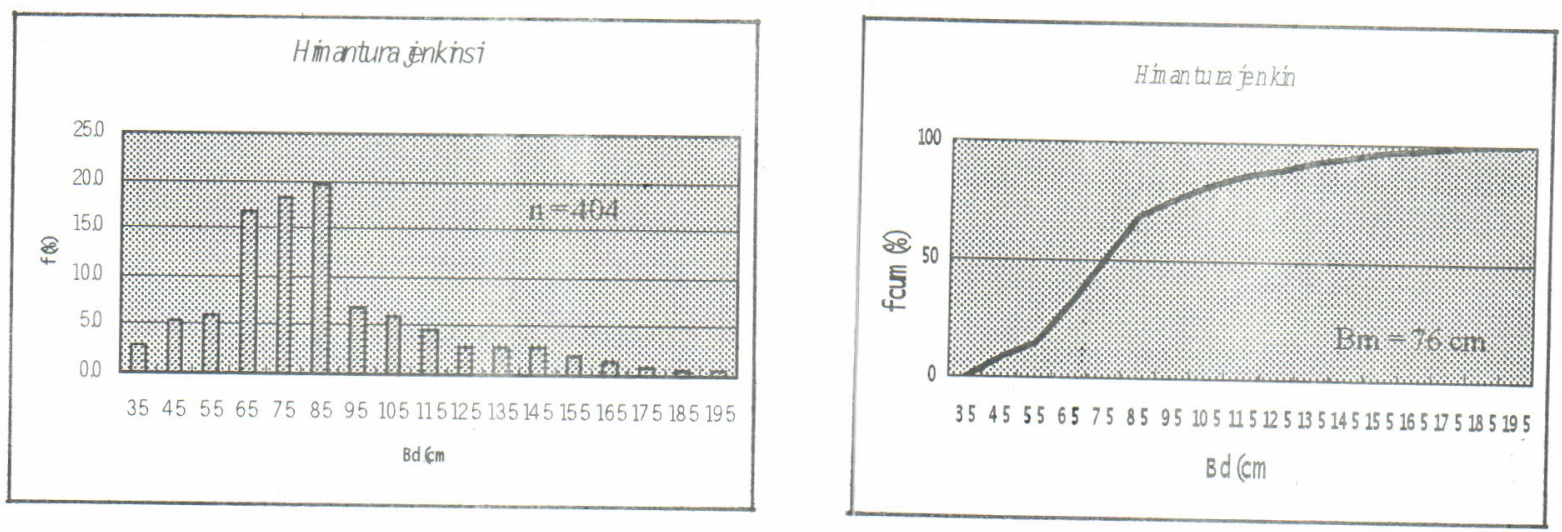

Gambar 7e. Sebaran ukuran lebar disk (Bd) dan frekuensi kumulatif ikan Himantura jenkinsi yang Figure 7e. Distribution of disk width $(B d)$ and commulative frequency of Himantura jenkinsi caught in the
Java Sea. 


\section{Selektivitas}

Selektivitas alat tangkap ikan adalah kemampuan menentukan target dalam menangkap ikan menurut jenis, kelamin, dan ukuran (atau kombinasi ketiganya) selama proses penangkapan dan memungkinkan semua hasil tangkapan non target diloloskan tanpa cidera (FAO, 1995). Selain itu, dikatakan juga bahwa selektivitas alat tangkap ikan adalah fungsi alat tangkap untuk menangkap ikan yang terbatas pada jenis dan ukuran ikan tertentu pada suatu populasi yang ditemui di daerah penangkapan (Arimoto, 1999; Tokai et al.,1996; Ferno and Steiner, 1994).
Tingkat selektivitas alat tangkap ikan pari diindikasikan dengan ukuran ikan pari yang tertangkap. Jika alat tangkap menangkap ikan pari dengan jumlah lebih dari $50 \%$ berukuran lebih kecil daripada ukuran Bm-nya maka dikatagorikan sebagai alat tangkap yang tidak selektif. Ikan pari yang mempunyai ukuran lebih kecil dari Bm-nya merupakan ikan pari muda yang belum pernah (sempat) beranak. Untuk melihat performansi selektivitas beberapa alat tangkap ikan terhadap ikan pari dominan di perairan Laut Jawa, telah dianalisis tiga alat tangkap yaitu jaring dogol, jaring liongbun, dan pancing senggol (Gambar 8).
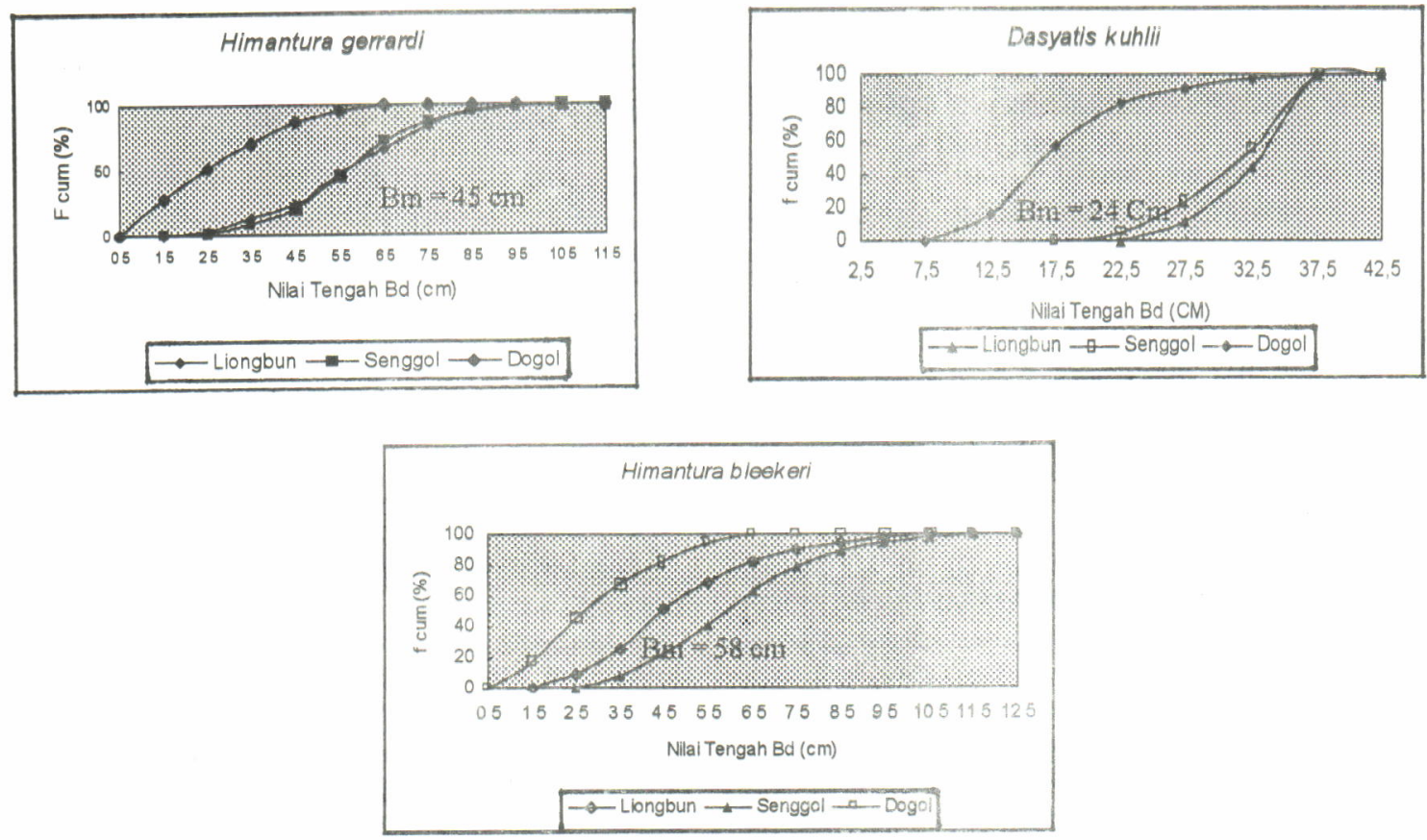

Gambar 8. Kurva selektivitas alat tangkap jaring dogol, jaring liongbun, dan pancing senggol terhadap ukuran ikan pari jenis Himantura gerrardi, Dasyatis kuhlii, dan Himantura bleekeri.

Figure 8. Selectivity curve of danish seine, bottom gillnet, and bottom longline without bait to the size of Himantura gerrardi, Dasyatis kuhlii, and Himantura bleekeri.

Dari Gambar 8 di atas dapat dijelaskan bahwa jaring dogol umumnya menangkap ikan pari jenis yang dominan $(H$. gerrardi, D.kuhlii, dan $H$. bleekeri) $>50 \%$ berukuran lebih kecil ukuran mulai dewasanya $\left(B_{m}\right)$. Sebaliknya alat tangkap ikan jaring liongbun dan pancing senggol menangkap ikan pari jenis dominan (H. gerrardi dan D.kuhlii) antara $17-25 \%$ berukuran $<\mathrm{B}_{\mathrm{m}}$-nya dan $\mathrm{H}$. bleekeri sekitar $52-80 \%$ berukuran lebih kecil dari $B_{m}$-nya. Kenyataan tersebut menunjukkan bahwa jaring dogol tergolong kurang selektif menangkap ikan pari karena sebagian besar tangkapannya ( $>50 \%$ ) berupa ikan pari muda. Jaring liongbun dan pancing senggol dapat dikatakan alat tangkap yang selektif, selektif menangkap ikan pari karena ikan pari yang tertangkap umumnya telah dewasa.
Jika dilihat dari lokasi di mana ikan pari tertangkap, maka ikan pari jenis dominan (H.gerrardi, D.kuhlii, dan $H$. bekri) tertangkap di daerah panangkapan dekat pantai (inshore fishing ground, $<12$ mil) dengan ukuran ikan yang relatif lebih kecil dibandingkan ikan yang tertangkap di daerah penangkapan jauh dari pantai (offshore fishing ground, > 12 mil). Gambar 9 menunjukkan kenyataan bahwa ikan pari jenis H.gerrardi, D.kuhlii, dan $H$. bleekeri yang tertangkap di daerah penangkapan inshore $67-80 \%$ belum dewasa, sedangkan yang tertangkap di daerah penangkapan offshore lebih dari $75 \%$ telah dewasa.

Perbedaan ukuran ikan pari antara yang tertangkap di daerah penangkapan inshore dan offshore salah satunya diduga karena perbedaan alat 

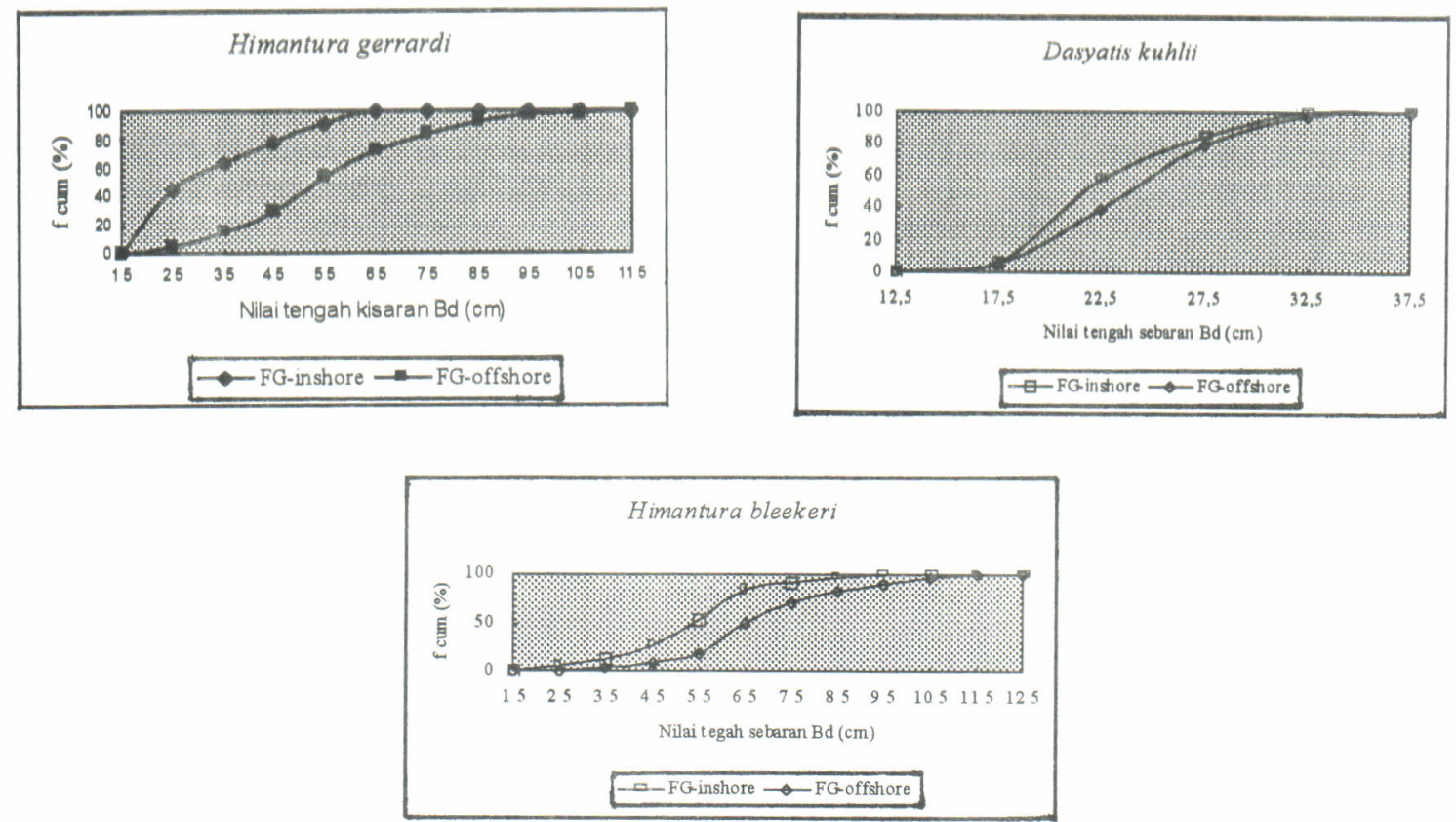

Gambar 9. Kumulatif persentase ikan pari jenis H.gerrardi, D. kuhlii, dan H.bleekeri yang tertangkap pada 2 daerah penangkapan berbeda (inshore dan offshore).

Figure 9. Percentage commulative of $\boldsymbol{H}$. gerradi, $\mathbf{D}$ khulii, and $\boldsymbol{H}$. bleekeri caught from different fishing grounds (inshore and offshore).

tangkap yang dioperasikan. Di daerah penangkapan inshore alat tangkap yang dioperasikan jaring dogol yang bersifat tidak selektif. Di daerah penangkapan offsore alat tangkap yang dioperasikan jaring liongbun dan pancing senggol yang bersifat selektif. Seperti disebutkan sebelumnya, jaring liongbun mempunyai ukuran mata jaring besar $(50 \mathrm{~cm})$ dan pancing sengggol mempunyai jarak pemasangan antar pancing $40-45 \mathrm{~cm}$ hanya menangkap ikan pari dengan ukuran yang relatif besar. Sedangkan jaring dogol dengan mata jaring lebih kecil dari 1 inci pada bagian kantongnya dan dioperasikan seperti halnya jaring trawl, mengakibatkan ikan pari yang tertangkap umumnya berukuran kecil dan belum dewasa.

\section{Tangkapan per Unit Upaya, CPUE}

Hasil tangkapan per unit upaya (catch per unit effort-CPUE) alat tangkap terhadap sumber daya ikan sering digunakan untuk menggambarkan indeks kelimpahan relatif sumber daya ikan di suatu wilayah perairan (Widodo at al.,2001). Analisis terhadap jenis dan jumlah alat tanggkap serta produksi ikan pari menurut Statistik Perikanan Indonesia (2002) dapat dinformasikan bahwa dari 10 alat tangkap yang menangkap ikan pari di Laut Jawa, alat tangkap dogol (cantrang) mempunyai hasil tangkapan per upaya (CPUE) tertinggi dibanding ke 9 alat tangkap lainnya. Selanjutnya jaring dogol (cantrang) ditetapkan sebagai alat tangkap standar ikan pari dengan nilai indek kemampuan tangkap-IKT (fishing power index$F P I)=1($ Tabel 2$)$.
Analisis terhadap upaya (unit) dengan standar alat tangkap jaring dogol (cantrang) dan hasil tangkapan (ton) ikan pari (Statistik Perikanan Indonesia 19972002) maka terlihat bahwa CPUE (ton/unit) ikan pari di Laut Jawa selama 7 tahun terakhir mengalami penurunan, dari 1,116 ton/unit pada tahun 1997 menjadi 0,822 ton/unit (2002) (Gambar 10). Menurunnya CPUE pada perikanan pari yang terjadi terus menurun sepanjang 7 tahun terakhir bisa digunakan sebagai indikasi telah terjadi tekanan penangkapan yang berlebihan

\section{Pengelolaan Sumber Daya Ikan Pari}

Selama ini sumber daya ikan pari di Laut Jawa kurang mendapat perhatian yang serius. Hal ini antara lain terlihat dari statistik perikanan baik kabupaten, provinsi, maupun nasional hanya mencatat ikan pari sebagai satu jenis saja. Padahal seperti diketahui bahwa jenis ikan pari yang ada di Laut Jawa paling tidak ada 36 jenis. Regulasi yang selama ini diundangkan berkaitan dengan eksploitasi sumber daya ikan secara umum, termasuk bagi sumber daya ikan pari adalah: (1) KEPPRES No. 39 Tahun 1980 yang secara garis besar mengatur adanya palarangan penangkapan ikan dengan menggunakan trawl, (2) KEPMENTAN No.392/Kpts/lK.120/Tahun 1999 pasal 7 yang mengatur ukuran mata jaring minimum alat tangkap ikan yaitu 1 inci, dan (3) KEPMENTAN No. 769/Kpts/HK.210/10/1988 yang mengatur penangkapan ikan dengan alat tangkap lampara dasar. Dari kenyataan tersebut juga menunjukkan 
Tabel 2. Jumlah alat tangkap, hasil tangkapan, hasil tangkapan per unit alat (CPUE) dan indek kemampuan tangkap (IKT) alat tangkap yang menangkap ikan pari tahun 2002 di Laut Jawa

Table 2. Number of fishing gear, landings, catch per unit fishing gear, and catching ability index of rays fishing gear in the Java Sea, 2002

\begin{tabular}{llcccc}
\hline No & \multicolumn{1}{c}{$\begin{array}{c}\text { Alat } \\
\text { Fishing Gear }\end{array}$} & $\begin{array}{c}\text { Jumlah Alat } \\
\text { (unit) }\end{array}$ & $\begin{array}{c}\text { Hasil Tngkapan } \\
\text { (Ton) }\end{array}$ & $\begin{array}{c}\text { Produksi per } \\
\text { Jumlah Alat }\end{array}$ & IKT(FPI) \\
\hline 1 & Dogol & 1290 & 1185,6 & 0,919 & 1,00 \\
2 & Payang & 14264 & 1510,3 & 0,106 & 0,12 \\
3 & Pukat Pantai & 3982 & 1095,1 & 0,275 & 0,30 \\
4 & Jr.Insang Hanyut & 12662 & 3079,2 & 0,243 & 0,26 \\
5 & Jr.Insang Tetap & 10308 & 4903,1 & 0,476 & 0,52 \\
6 & Jr.Trammel & 13033 & 374,6 & 0,029 & 0,03 \\
7 & Rawai & 2746 & 1167,9 & 0,425 & 0,46 \\
8 & Pancing & 13085 & 1098,4 & 0,084 & 0,09 \\
9 & Sero & 363 & 87,2 & 0,240 & 0,26 \\
10 & Bubu & 8809 & 164,6 & 0,019 & 0,02 \\
\hline
\end{tabular}

Hasil analisis dari Statistik Perikanan Propinsi DKI Jaya, Jabar, Jateng, Jatim, dan KalSel (2002)

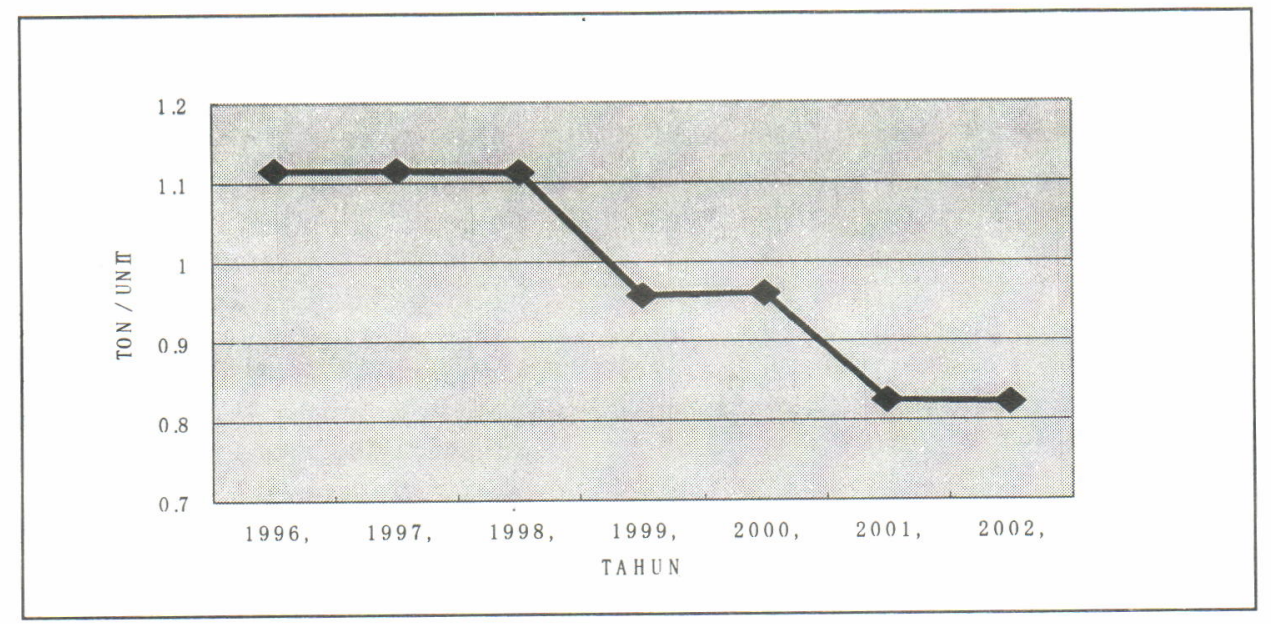

Gambar 10. CPUE ikan pari di Laut Jawa selama tahun 1996-2002 dengan alat tangkap baku dogol (cantrang).

Figure 10. CPUE of rays in the Java Sea in 1996-2002 by effort standard of danish seine.

bahwa sumber daya ikan pari memang belum ada pengelolaan yang khusus.

Hasil analisis terhadap alat tangkap yang selama ini mengeksploitasi ikan pari paling efektif yaitu jaring dogol menunjukkan bahwa alat tangkap tersebut bersifat tidak selektif. Hal tersebut ditunjukkan dengan hasil tangkapan ikan pari yang umumnya berukuran kecil dan masih muda. Penangkapan ikan muda akan mengakibatkan degradasi stok secara cepat. Karena ikan-ikan muda yang tertangkap belum sempat melahirkan. Alat tangkap penting lain yang selama 2-3 tahun dikhususkan untuk mengekploitasi ikan pari adalah jaring liongbun dan pancing senggol. Hasil analisis menunjukkan bahwa kedua alat tangkap tersebut termasuk alat yang mempunyai tingkat selektivitas yang baik. Hal tersebut ditunjukkan dengan hasil tangkapan ikan pari yang umumnya telah dewasa (> 50\%).
Hasil analisis terhadap ikan pari yang tertangkap di daerah penangkapan (fishing ground) inshore dan offshore, menunjukkan bahwa ikan pari yang tertangkap di perairan pinggir (inshore) dengan alat tangkap utama jaring dogol yang dioperasikan oleh armada kapal ukuran 6-12 GT umumnya berukuran kecil dan muda. Ikan pari yang tertangkap di daerah penangkapan jauh dari pantai (offshore) dengan alat tangkap terutama pancing senggol dan jaring liongbun yang menggunakan kapal berukuran $>30$ GT umumya berukuran besar dan telah dewasa. Dilihat dari hasil tangkapan per upaya (CPUE)-nya, di mana terjadi penurunan sepanjang 7 tahun terakhir adalah mengindikasikan telah terjadi kondisi lebih tangkap (over fishing).

Seperti telah disebutkan sebelumnya bahwa sumber daya ikan pari tergolong sumber daya ikan yang rentan terhadap tekanan penangkapan. Hal ini 
disebabkan ikan pari mempunyai karakter biologi sebagai berikut: tumbuh lamban, matang seksual pada umur relative tua, fekunditas rendah, dan perumur panjang. Didasarkan bukti-bukti ilmiah tersebut, maka beberapa opsi pengelolaan bagi sumber daya ikan pari di Laut Jawa yang dapat dilaksanakan adalah: (1) Jika kebijakan ditujukan bagi pengembangan teknologi alat tangkap ikan pari, maka alat tangkap yang mempunyai peluang untuk dikembangkan adalah pancing senggol dan jaring liongbun, karena kedua jenis alat tangkap tersebut bersifat selektif. Pancing senggol didesain dengan konstruksi pemasangan antar tali cabang (branch line)-nya 40-45 cm dan jaring liongbun dengan ukuran mata minimum $50 \mathrm{~cm}$. (2) Kegiatan penangkapan ikan pari hendaknya dilakukan pada daerah penangkapan di tengah (offshore). Konsekuensinya adalah harus mengembangkan armada kapal berukuran > 30 GT sehingga mampu melakukan operasi penangkapan di daerah penangkapan offshore.

\section{KESIMPULAN DAN SARAN}

\section{Kesimpulan} bahwa:

Dari paparan di atas, maka dapat disimpulkan

1. Terdapat sedikitnya 36 jenis (spesies) ikan pari di perairan Laut Jawa, yang didominasi jenis Himantura gerrardi $(30,07 \%)$, Dasyatis kuhlii $(18,57 \%)$, Himantura bleekeri (11,58\%), Aetoplatea zonura $(6,28 \%)$, dan Himantura jenkinsii $(5,36 \%)$.

2. Alat tangkap penting yang selama ini digunakan untuk menangkap ikan pari di Laut Jawa yaitu: jaring dogol, jaring liongbun, dan pancing senggol.

3. Jaring dogol bersifat tidak selektif dimana lebih dari $50 \%$ ikan pari yang tertangkap berukuran kecil dan masih muda (juvenile). Jaring liongbun dan pancing senggol tergolong alat tangkap yang bersifat selektif bagi sumber daya ikan pari, karena mampu menangkap ikan pari ukuran besar dan telah dewasa.

4. Daerah penangkapan ikan pari di Laut Jawa dapat digolongkan menjadi dua, yaitu inshore (<12 mil) dan offshore (>12 mil). Pada daerah penangkapan inshore ikan pari yang tertangkap umumnya berukuran kecil dan masih muda. Adapun pada daerah penangkapan offshore. ikan pari yang tertangkap umumnya berukuran besar dan telah dewasa.

5. Terjadi penurunan CPUE ikan pari dari 1,116 ton/unit pada tahun 1997 menjadi 0,822 ton/unit (2002).
6. Sampai saat ini belum ada langkah pengelolaan khusus bagi sumber daya ikan pari di Laut Jawa.

\section{Saran}

1. Pengembangan alat tangkap ikan pari agar ditujukan bagi pancing senggol dan jaring liongbun.

2. Kegiatan penangkapan ikan pari hendaknya dilakukan pada daerah penangkapan (fishing ground) di tengah (offshore) $>12$ mil.

\section{DAFTAR PUSTAKA}

Arimoto, T., 1999. Fish behavior for improving fish capture technology. Tokyo University of Fisheries. Japan, $55 \mathrm{pp}$.

Compagno. L.J.V.,1999. The living marine resource of the Western Central Pacific Vol. 3 FAO. Rome, p:1398--1529.

Direktorat Jenderal Perikanan Tangkap. 2002. Statistik Perikanan Indonesia. Departemen Kelautan dan Perikanan. Jakarta.

Durand, J.R. \& D. Petit. 1997. The Java Sea environtment. BIODINEX. Java Sea Pelagic Fishery Assessment Project, p: 15--38

FAO, 1995. Code of conduct for responsible fisheries. FAO. Rome, $41 \mathrm{pp}$.

Ferno, F. \& S.Olsen, 1994. Marine fish behavior in capture and abundance estimation. Fishing News Book. London, 222 pp.

Isa,M.M., H.Kohno, Hitoshi Ida, H.T.Nakamura, A.Zaenal, \& S.A.S.A. Kadir. 1998. Field guide to impotrant commercial marine fishes of the South China Sea. SEAFDEC. Malaysia, 285 pp.

Tarp, T.G. \& P.J. Kailola. 1982. Trawled fishes of Southern Indonesia and North-Western Australia. ADAB, GDF and GTZ. Singapore, 406 pp.

Tokai, T., S.Omoto, R.Sato \& K.Matuda. 1996. A method of determining selectivity curve of separator grid. Fishery Research. Elsevier Science BV, 27: 51--60.

Widodo,J., O.K.Sumadhiharga, \& A. Djamali. 2001. Pengkajian sumber daya perikanan laut (fisheries stock assessment). Penuntun pengkajian stok sumber daya ikan perairan Indonesia. BRKP-DKP dan P2O-LIPI. Jakarta, p: 1--20. 